\title{
A Comparison of Proteins and Peptides as Substrates for Microsomal and Solubilized Oligosaccharyltransferase
}

\author{
Yun-Li Liu, Geoffrey C. Hoops and James K. Coward* \\ Department of Chemistry and Interdepartmental Program in Medicinal Chemistry, College of Pharmacy, \\ University of Michigan, Ann Arbor, MI 48109-1055, U.S.A.
}

\begin{abstract}
A chemoenzymatic synthesis of homogeneous neoglycoproteins and glycopeptides was explored using oligosaccharyltransferase isolated from yeast. Neither the microsomal form nor the solubilized form of the enzyme catalyzed the transfer of the core $\mathrm{Glc}_{3} \mathrm{Man}_{9}(\mathrm{GlcNAc})_{2}$ oligosaccharide to chemically modified ribonuclease $\mathrm{A}$ or $\alpha$-lactalbumin. Similarly, no transfer was observed to the 32-amino acid peptide hormone, calcitonin, by either the membrane-bound or soluble form of oligosaccharyltransferase. However, a 17-amino acid fragment of yeast invertase with the unusual sequence containing two overlapping glycosylation sequons proved to be a good substrate, slightly less effective than the well studied tripeptide, Bz-AsnLeu-Thr- $\mathrm{NH}_{2}$. Product analysis using gel permeation chromatography showed that the expected glycopeptides were formed and endo H-catalyzed cleavage of the oligosaccharide portion from the glycopeptides demonstrated that the glycopeptides contained the same carbohydrate moiety.
\end{abstract}

\section{Introduction}

Oligosaccharyltransferase (OST, EC 2.4.1.119) catalyzes the reaction shown in Equation 1 . This is a co-translational process, occurring in the endoplasmic reticulum as the growing peptide is exiting the ribosomal complex. I In addition, this is an unusual chemical reaction involving apparent nucleophilic attack by an amide nitrogen on $\mathrm{C}-1$ of the terminal sugar in a lipid-linked oligosaccharide. The literature contains a large body of data on the biochemistry and enzymology of the biosynthesis of the lipidoligosaccharide (LOS) substrate, i.e. the so-called dolichol cycle ${ }^{2}$ as well as the glycosidases and glycosyltransferases involved in the processing of the initial product of Equation 1.3,4 However, much less is known about the detailed biochemistry of the OSTcatalyzed reaction; 5 the purification of a multiprotein complex required for catalysis of Equation 1 has been reported only recently. 6,7 This complex, isolated from canine pancreas, consists of three non-identical subunits: $66 \mathrm{kDa}$ (ribophorin I), $63 \mathrm{kDa}$ (ribophorin II), and $48 \mathrm{kDa}$. A very exciting result of this purification is the finding that the mammalian $48 \mathrm{kDa}$ protein has 25 $\%$ identity to an essential yeast protein, WBP1.7 Independent studies have shown that WBP1 is not only essential for yeast OST activity but is also critical for yeast replication. ${ }^{8,9}$ These experimental data point to the key role of $\mathrm{N}$-linked glycosylation in cell survival although the exact role of the oligosaccharides in glycoprotein function is not understood. $10-13$

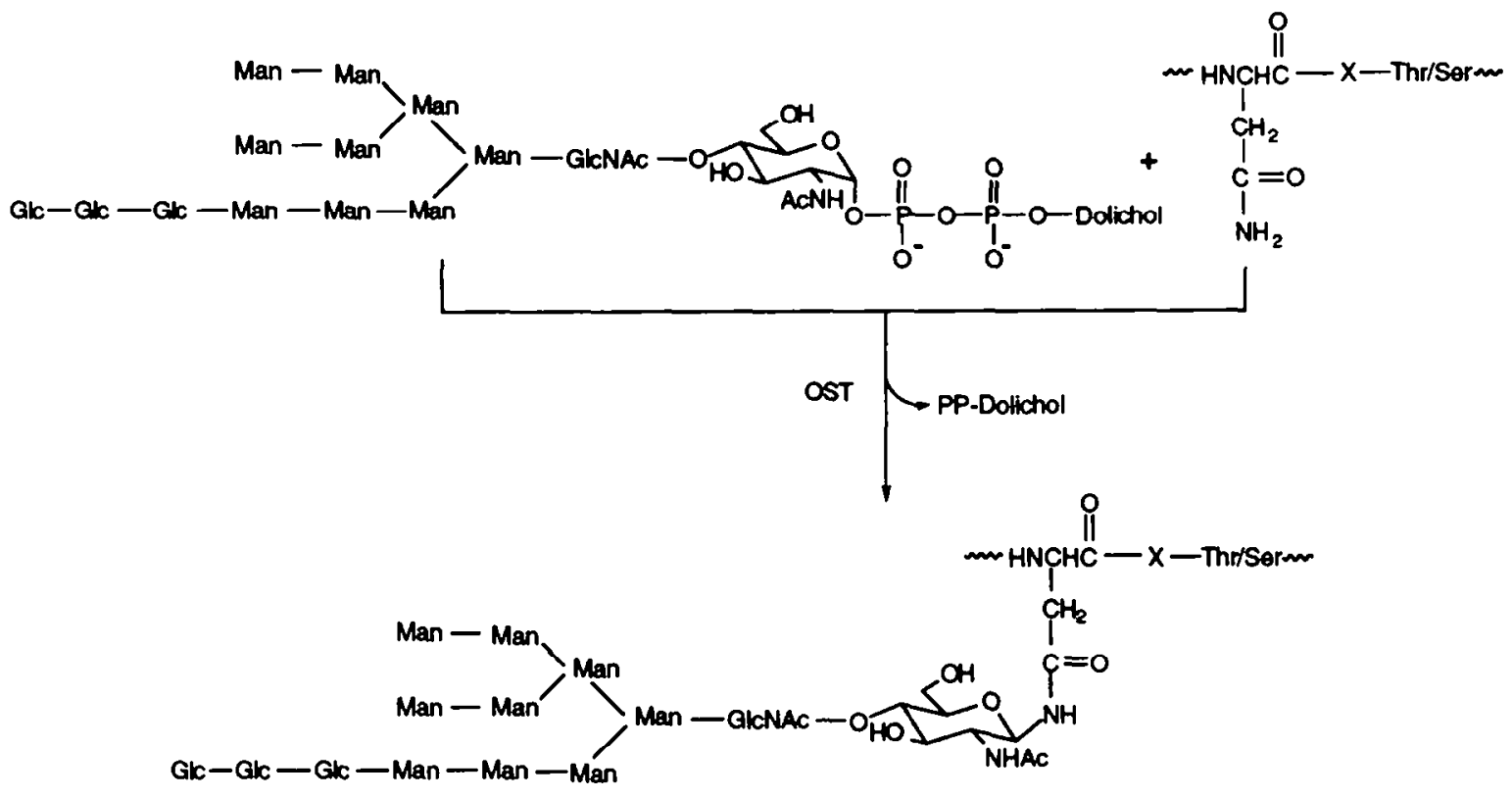


We have initiated a research program aimed at understanding the mechanism of the reaction catalyzed by OST. Prior work in several laboratories has shown that small peptides are effective OST substrates. ${ }^{14-16}$ Less extensive studies have indicated that truncated lipidoligosaccharides can be used as oligosaccharide donors in the OST-catalyzed reaction. ${ }^{16-18}$ In addition, solubilization of the membrane-bound OST activity leads to good recovery of activity and allows for the initial quantitative characterization of the OSTcatalyzed reaction in terms of substrate structural requirements, ${ }^{19} \mathrm{Mn}^{2+}$ - and $\mathrm{pH}$-dependence, ${ }^{19}$ and the stimulation of OST activity by membrane lipids. ${ }^{20.21}$ In our initial research, we have used both biosynthetic L OS 22 and the chitobiose derivative, a lipiddisaccharide (LDS), 23 in order to establish rigorously the structure of the glycopeptide product. We have also used chemically synthesized LDS to effect an OST-catalyzed glycosylation of the tripeptide, Bz-AsnLeu-Thr- $\mathrm{NH}_{2}$, on a sufficiently large scale so as to allow for comparison of the chemoenzymatic product with the chitobiose-containing glycopeptide which was also synthesized via a more classical non-enzymatic route. 23 We have used this system to explore two possible catalytic mechanisms by looking for deuterium wash-out during OST catalysis. Glycopeptides isolated from OST-catalyzed glycosylation of $2 \mathrm{H}$-labeled peptide substrates were analyzed by ${ }^{1} \mathrm{H}$ NMR and no ${ }^{2} \mathrm{H}$ washout was observed, thus ruling out two 'nucleophilic activation' mechanisms of OST catalysis. ${ }^{24}$

The present research focuses on the use of OST to catalyze the glycosylation of proteins and large peptides. We wished to use homogeneous neoglycoproteins and/or glycopeptides for NMR studies which would address the influence of appended carbohydrates on the structure of the protein moiety of $\mathrm{N}$-linked glycoproteins. Conversely, the influence of the surrounding protein on the structure of a pendant oligosaccharide could also be studied. In a manner analogous to the chemoenzymatic synthesis employed in our recent NMR studies of glycopeptides, ${ }^{24}$ we would be able to access sufficient quantities of the desired neoglycoproteins using OST as the catalyst. We were encouraged by two papers from the Lennarz group in the late $1970 \mathrm{~s}$ which reported the OST-mediated glycosylation of chemically modified ribonuclease $A$ (RNase A), $\alpha$-lactalbumin ( $\alpha$-Lac), and ovalbumin. 25,26 Of particular interest was the report of the ability to glycosylate RNase $A$ since there is a tremendous amount of structural information on the nonglycosylated form (RNase A) of this extensively studied enzyme. Very little structural information is available on the glycosylated form, RNase B. ${ }^{27}$ In this paper, we report the results of our studies on the use of OST to effect the glycosylation of proteins and large peptides.

\section{Results}

In the present work we have investigated the glycosylation of modified proteins and large peptides in a reaction catalyzed by oligosaccharyltransferase (OST) isolated from yeast. As a prelude to more extensive investigations using purified OST, we wished to compare the microsomal and solubilized forms of the enzyme in these reactions. In order to establish that the solubilized enzyme led to the synthesis of the same glycopeptide product as that obtained from the microsomal form, the tripeptide substrate, Bz-Asn-LeuThr- $\mathrm{NH}_{2}$, was glycosylated using ${ }^{3} \mathrm{H}-1$ abelled lipidoligosaccharide $\left({ }^{3} \mathrm{H}\right.$-LOS $)$. The glycopeptide was isolated and analyzed by gel filtration chromatography as previously described. ${ }^{20,22}$ The chromatographic data shown in Figure 1 are very similar to those previously reported for the glycopeptide product isolated from the

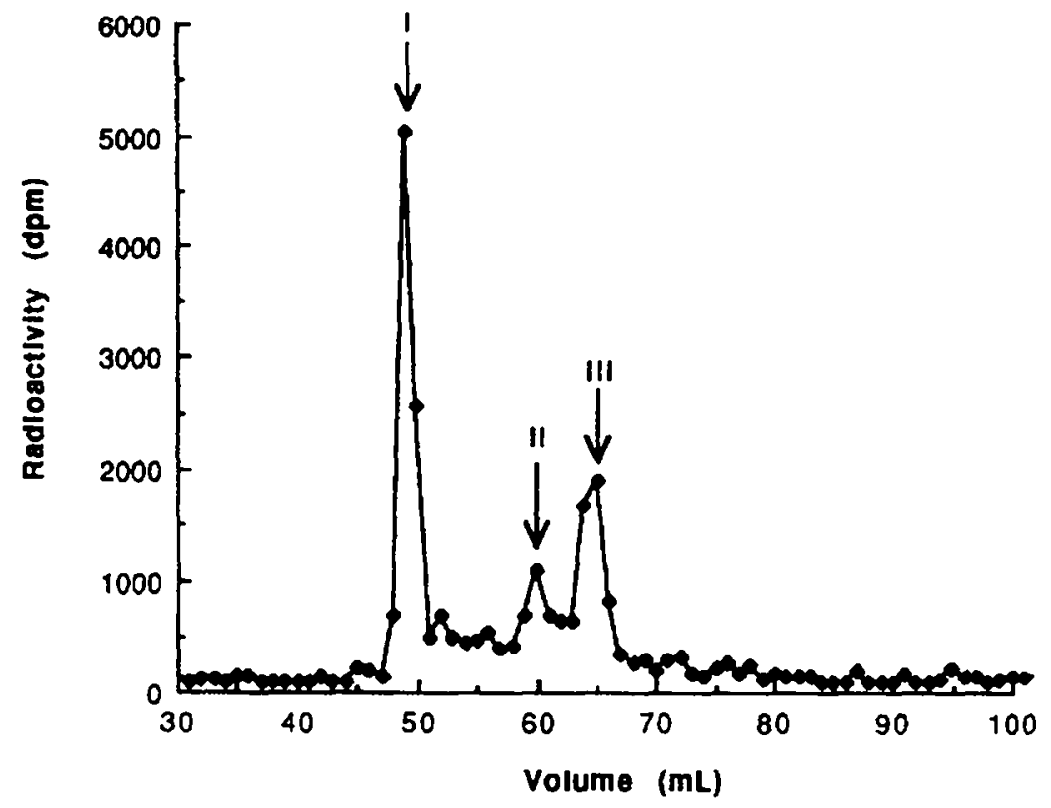

Figure 1. Gel filtration (Bio-Gel P-4) of glycopeptide product obtained from solubilized OST-catalyzed glycosylation of Bz-Asn-Leu-Thr-NH ${ }_{2}$ by $\left[{ }^{3} \mathrm{H}\right]$ LOS. 
reaction catalyzed by the microsomal enzyme. ${ }^{22}$ Thus, solubilization of the membrane-bound OST leads to a functional enzyme which is able to catalyze the reaction of interest. With these data in hand, the comparison of microsomal vs solubilized OST as catalysts for the glycosylation of proteins was initiated.

As noted in the Introduction, data in the literature indicated that several proteins were substrates only if they were modified by chemical methods. ${ }^{25,26}$ The data given in Table 1 , Section $A$, show that the modified proteins are extremely poor OST substrates. Comparison of the distribution of ${ }^{3} \mathrm{H}$ in various fractions after OSTcatalyzed glycosylation of endogenous P40 proteins, i.e. no added tripeptide substrate (line 1), vs that observed in the presence of the tripeptide (line 2) shows, as expected, the almost complete inhibition of protein glycosylation (SDS-soluble) in favor of peptide glycosylation ( $\mathrm{H}_{2} \mathrm{O}$-soluble). It was expected that OSTcatalyzed glycosylation of the exogenous modified proteins would lead to an increase of the ${ }^{3} \mathbf{H}$ transferred from $\left[{ }^{3} \mathrm{H}\right] L O S$ to glycoproteins (SDS fraction). Surprisingly, a marked decrease in the ${ }^{3} \mathrm{H}$-labelled glycoprotein was observed when the modified proteins were used as potential OST substrates. These data suggest that the modified proteins are capable of inhibiting the glycosylation of endogenous proteins but that the former are not themselves effective OST substrates. This conclusion was confirmed by direct analysis of the reaction mixtures by polyacrylamide gel electrophoresis (PAGE) and by Bio-Gel P-6 chromatography as described in the Experimental Section. Only ${ }^{3} \mathrm{H}$-LOS was observed as a distinct peak; less than $2 \%$ of the applied radioactivity eluted as expected for the desired glycoproteins (data not shown). Similar analysis of both the $\mathrm{H}_{2} \mathrm{O}$-soluble and SDSsoluble fractions by PAGE and Bio-Gel P-4 chromatography demonstrated the absence of ${ }^{3} \mathrm{H}$ labelled glycoproteins in those specific fractions.

We have also carried out similar experiments with solubilized OST activity, isolated as described in the Experimental Section. The data in Table 2, Section A, lead to the same conclusions as those just described for the microsomal enzyme, i.e. neither sulfitolyzed nor $S$ carboxamidomethyl RNase $A$ is a substrate for the solubilized OST. In contrast, the data of Table 2 show that Bz-Asn-Leu-Thr- $\mathrm{NH}_{2}$ is a good substrate leading to the expected glycopeptide product (Figure 1) as already discussed.

While the failure to observe significant glycosylation of modified proteins was a disappointment in terms of using this chemoenzymatic approach for the synthesis of homogeneous neoglycoproteins, it seemed appropriate to ascertain what structural limitations are associated with OST-catalyzed protein/peptide glycosylation. Prior reports in the literature are in conflict as to the ability of calcitonin, a 32-amino acid hormone, to serve as an OST substrate. ${ }^{14,28}$ This peptide

Table 1. ${ }^{3} \mathrm{H}$-Labelled products (\%) obtained from reaction mixtures using various protein or peptide substrates, $\left[{ }^{3} \mathrm{H}\right] L O S$, and microsomal OST

\begin{tabular}{|c|c|c|c|c|c|c|}
\hline Added Substrate ${ }^{b}$ & $\mu \mathrm{M}$ & $\mathrm{P} 40$ & $2: 1^{c}$ & $\mathrm{HhO}^{\mathrm{d}}$ & $1103^{e}$ & $\operatorname{SDS}^{\mathrm{f}}$ \\
\hline \multicolumn{7}{|l|}{ (A) } \\
\hline None & - & + & $22.8,20.9$ & $11.1,12.0$ & $35.5,38.7$ & $30.5,28.4$ \\
\hline Bz-Asn-Leu-Thr- $\mathrm{NH}_{2}$ & 360 & + & $18.1,24.9$ & $27.8,29.2$ & $48.4,39.9$ & $5.6,6.0$ \\
\hline $\mathrm{RA}-\left(\mathrm{SSO}_{3}{ }^{-}\right)_{8}$ & 140 & + & $26.4,27.0$ & $23.5,24.5$ & $41.2,38.2$ & $8.8,10.3$ \\
\hline Lac- $\left(\mathrm{SCH}_{2} \mathrm{CO}_{2}^{-}\right)_{8}$ & 140 & + & $29.4,24.1$ & $42.1,46.1$ & $24.0,23.8$ & $4.4,6.1$ \\
\hline Lac- $\left(\mathrm{SCH}_{2} \mathrm{CONH}_{2}\right)_{8}$ & 140 & + & $29.1,28.6$ & $33.7,33.9$ & $29.3,30.2$ & $7.8,7.2$ \\
\hline \multicolumn{7}{|l|}{ (B) } \\
\hline None & - & + & $22.3,24.4$ & $12.8,18.4$ & $41.1,32.7$ & $23.8,24.4$ \\
\hline Calcitonin & 150 & + & 28.4 & 16.4 & 32.7 & 22.5 \\
\hline None ${ }^{g}$ & - & + & 31.7 .21 .9 & 22.6 .24 .4 & $12.7,10.2$ & $32.9,43.5$ \\
\hline Calcitonin $\mathrm{g}$ & 150 & + & 27.9 & 23.8 & 33.6 & 14.7 \\
\hline \multicolumn{7}{|l|}{ (C) } \\
\hline None & - & + & $8.9,9.3$ & 15.7 .18 .1 & 35.5 .35 .6 & $39.9,36.9$ \\
\hline IVT-Asn & 360 & + & $11.2,14.2$ & $39.6,38.3$ & $38.5,35.6$ & $10.7,11.9$ \\
\hline IVT-Gln & 360 & + & $15.9,7.8$ & $23.9,26.7$ & 39.9 .45 .0 & 20.2 .20 .4 \\
\hline
\end{tabular}

\footnotetext{
${ }^{2}$ For scheme showing separation of substrates and products in addition to details of the separation procedure, see Clark et al..$^{22}$ Incubation time for modified proteins, $2 \mathrm{~h}$; for calcitonin, $90 \mathrm{~min}$; for invertase peptides, $30 \mathrm{~min}$. ${ }^{\mathrm{h}} \mathrm{Abbreviations}$ used for protein or peptide substrates: $\mathrm{RA}^{-}\left(\mathrm{SSO}_{3^{-}}\right)_{8}$. sulfitolyzed ribonuclease $\mathrm{A}$ : Lac-( $\left.\mathrm{SCH}_{2} \mathrm{CO}_{2}-\right)_{8}$, S-carboxymethylated $\alpha$-lactalbumin; Lac-( $\left(\mathrm{SCH}_{2} \mathrm{CONH}_{2}\right)_{8}, \mathrm{~S}$-carboxamidomethylated $\alpha$ lactalbumin; IVT-Asn, peptide corresponding to yeast invertase sequence from 82-98. IVT-GIn, peptide corresponding to yeast invertase sequence from 82-98 except with Gln in place of Asn ${ }^{92}$. ${ }^{C}$ Lipid-linked carbohydrates containing ${ }^{3} \mathrm{H}$-mannose derived from ${ }^{3} \mathrm{H}$-LOS biosynthesis. ${ }^{d}$ Glycopeptide. ${ }^{\text {Unreacted }}{ }^{3} \mathrm{H}$-LOS substrate. ${ }^{\mathrm{f}}$ Glycoproteins. ${ }^{8}$ Assay run in the presence of $10 \mathrm{mM}$ DTT.
} 
Table 2. ${ }^{3} \mathrm{H}$-Labelled products (\%) obtained from reaction mixtures using various protein or peptide substrates, $\left[{ }^{3} \mathrm{H}\right] L O S$, and solubilized $O S T$ "

\begin{tabular}{|c|c|c|c|c|}
\hline Added Substrate ${ }^{b}$ & $\mu \mathrm{M}$ & $70 \% \mathrm{MeOH}^{\mathrm{c}}$ & $1103^{d}$ & SDSe \\
\hline \multicolumn{5}{|l|}{ (A) } \\
\hline None & - & $11.4,11.4$ & $37.8,31.4$ & 50.8 .57 .1 \\
\hline Bz-Asn-Leu-Thr- $\mathrm{NH}_{2}$ & 360 & $73.8,72.8$ & $13.3,15.0$ & $13.0,12.2$ \\
\hline $\mathrm{RA}-\left(\mathrm{SSO}_{3}\right)_{8}$ & 100 & 8.6 & 43.9 & 47.5 \\
\hline $\mathrm{RA}-\left(\mathrm{SCH}_{2} \mathrm{CONH}_{2}\right)_{8}$ & 100 & $8.9,15.5$ & $37.2,28.3$ & $53.9,56.1$ \\
\hline \multicolumn{5}{|l|}{ (B) } \\
\hline None & - & $11.9,16.2$ & 61.7.57.4 & 26.3.26.5 \\
\hline Bz-Asn-Leu-Thr- $\mathrm{NH}_{2}$ & 360 & $39.7,37.9$ & 47.9. 49.8 & 12.4. 12.3 \\
\hline Calcitonin & 150 & 14.6 & 61.3 & 24.1 \\
\hline IVT-Asn & 360 & 33.9 .30 .3 & 51.9 .55 .7 & 14.2. 14.0 \\
\hline IVT-Gln & 360 & $16.4,19.5$ & 60.6 .57 .4 & $23.0,23.1$ \\
\hline
\end{tabular}

\footnotetext{
"Separation of substrates and products performed as described by Chalifour and Spiro. ${ }^{20}$ Incubation time for modified protein substrates, $2 \mathrm{~h}$; for calcitonin and invertase peptide substrates, $30 \mathrm{~min}$. 'b Abbreviations used for substrates are given in Table 1, footnote 'b'. 'Glycopeptide. ${ }^{\mathrm{d}}$ Unreacted $\left[{ }^{3} \mathrm{H}\right] \mathrm{LOS} .{ }^{e}$ Glycoproteins.
}

contains one glycosylation site within a disulfide loop: ...-Cys-Ser-Asn-Leu-Ser-Thr-Cys-..., but this is not glycosylated in vivo. As shown in Table 1, Section B, the lack of significantly increased radioactivity in the glycopeptide fraction $\left(\mathrm{H}_{2} \mathrm{O}\right)$ indicates that calcitonin failed to act as an OST substrate. In addition, it should be noted that the glycoprotein fraction (SDS) was not significantly reduced in the presence of calcitonin (line 2) vs that observed in the absence of calcitonin (line 1). In order to ascertain if the disulfide loop is an impediment to glycosylation, the reactions were repeated in the presence of dithiothreitol (DTT). The data shown in Table 1 , Section $B$, again show no significant increase in the formation of glycopeptide ( $\mathrm{H}_{2} \mathrm{O}$ fraction) when calcitonin was assayed as a possible substrate in the presence of DTT. The glycosylation of endogenous protein appears to be markedly reduced in the presence of calcitonin (line 4) vs that observed in the absence of calcitonin (line 3). However, the effects of DTT on the variety of acceptor proteins and/or the LOS substrate are not well studied. Thus, the distribution of radioactivity in the non-peptide control (line 3 ) is not well documented in terms of structural identification of products. The absence of significant OST-catalyzed glycosylation of calcitonin was confirmed by gel chromatography as described in the Experimental Section; no radioactivity was observed other than that which could be attributed to the ${ }^{3} \mathrm{H}$-LOS substrate. Similar results for calcitonin were obtained with solubilized OST (Table 2).

The multiple glycosylation sites in invertase have been investigated in detail by Maley and co-workers. ${ }^{29}$ Of the 14 potential glycosylation sites, seven are always glycosylated while six are glycosylated to varying degrees. One site $\left(\mathrm{Asn}^{93}\right)$ is never glycosylated and is part of an unusual pair of overlapping sequons, ...Asn ${ }^{92}$.
Asn ${ }^{93}$-Thr-Ser-.... In collaboration with Dr Maley, we have initiated an investigation of the OST-catalyzed glycosylation of invertase peptides. Our first efforts have involved a 17-amino acid peptide containing the overlapping sequons. As shown in Table 1, Section C, both the parent peptide containing the overlapping sequons, IVT-Asn, and a synthetic 'mutant' peptide, IVT-GIn, containing Gln in place of $\mathrm{Asn}^{92}$, result in significant formation of glycopeptide. As shown previously, glycopeptides appear in the $\mathrm{H}_{2} \mathrm{O}$ fraction. Competition for the OST active site results in decreased glycosylation of endogenous $\mathrm{P} 40$ proteins, thus leading to a decrease in the SDS fraction containing the glycoproteins. Similar results for the invertase peptides were obtained with solubilized OST (Table 2). A graphical representation of the data in Table 2, Section $B$, is shown in Figure 2. These data show that glycosylation of IVT-Asn proceeds at a somewhat slower rate than glycosylation of Bz-Asn-Leu-Thr- $\mathrm{NH}_{2}$, but at a faster rate than IVT-Gin. Glycosylation of calcitonin is insignificant under these reaction conditions.

Characterization of the glycopeptide product obtained from OST-catalyzed glycosylation of the invertase peptides, IVT-Asn and IVT-GIn, was carried out as previously described for the tripeptide substrate, $\mathrm{Bz}$ Asn-Leu-Thr- $\mathrm{NH}_{2}{ }^{22} \mathrm{Gel}$ chromatography of the $\mathrm{H}_{2} \mathrm{O}$ soluble glycopeptide product showed a broad peak eluting at a position consistent with the size of the anticipated glycopeptides (Figure 3). Removal of the carbohydrate by endo $\mathrm{H}$-catalyzed hydrolysis leads to the identical oligosaccharide domain from both glycopeptides as shown in Figure 4. Consistent with the data of Tables 1 and 2, and also Figure 2, the amount of glycopeptide (Fig. 3) and derived oligosaccharide (Fig. 4) is markedly reduced for IVT-Gln vs IVT-Asn. 


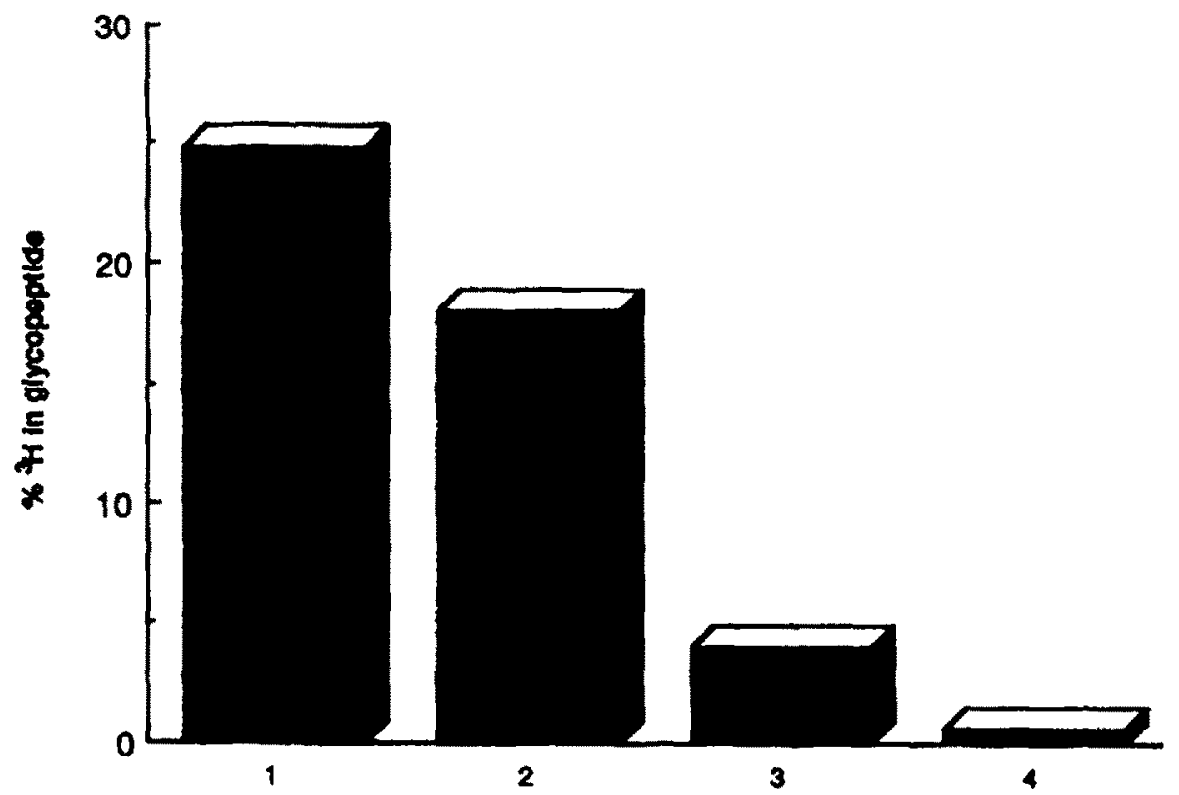

Figure 2. Conversion of peptides to glycopeptides based on the incorporation of ${ }^{3} \mathbf{H}$ from $\left[{ }^{3} \mathbf{H}\right.$ LOS into [ ${ }^{3} \mathbf{H}$ glycopeptides using solubilized OST and a 30 min incubation at ambient temperature. Data shown are the average of duplicate determinations for each peptide as given in Table 2 , Section B. 1. Bz-Asn-Leu-Thr-NH $\mathrm{N}_{2}$; 2. IVT-Asn; 3. IVT-GIn; 4, calcitonin.

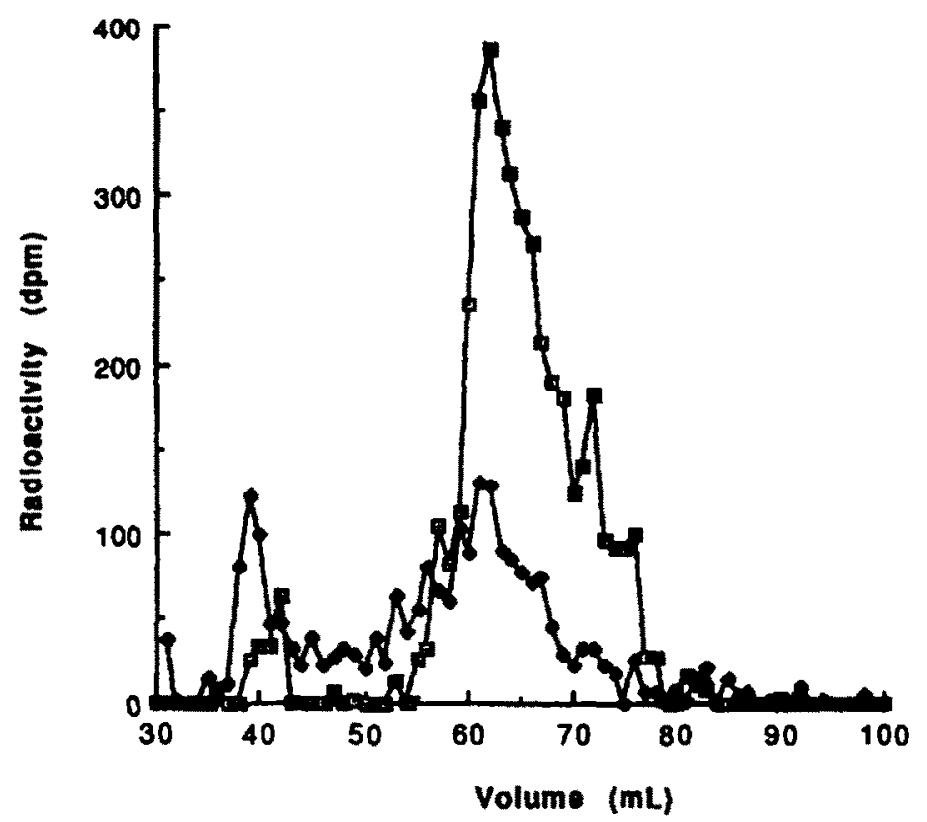

Figure 3. Gel filtration (Bio-Gel P-6) of glycopeptide product obtained from microsomal OST-catalyzed glycosylation of the invertase peptides, IVT-Asn(D) or IVT-Gln (*) by [ ${ }^{3} \mathrm{H}$ LLOS.

\section{Discussion}

In an attempt to develop a chemoenzymatic synthesis of homogeneous neoglycoproteins, we have investigated the oligosaccharyltransferase-catalyzed reaction between lipid-linked oligosaccharides and several modified proteins or peptides. The reactions have been studied using both microsomal and solubilized OST. Several modified proteins were assayed as potential OST substrates, using both the microsomal (Table 1) and solubilized enzyme (Table 2). As previously reported, ${ }^{22}$ the tripeptide, Bz-Asn-Leu-Thr- $\mathrm{NH}_{2}$, is a good substrate and its glycosylation competes with the glycosylation of endogenous proteins of the microsomal P40 fraction. This competition is shown in Section A of Tables 1 and 2 for the microsomal and solubilized OST activity, respectively. Thus, with the microsomal OST (Table 1), ca $30 \%$ of the ${ }^{3} \mathrm{H}$ is glycoprotein (SDS fraction) in the absence of tripeptide substrate, whereas in the presence of tripeptide substrate, only ca $5 \%$ of 


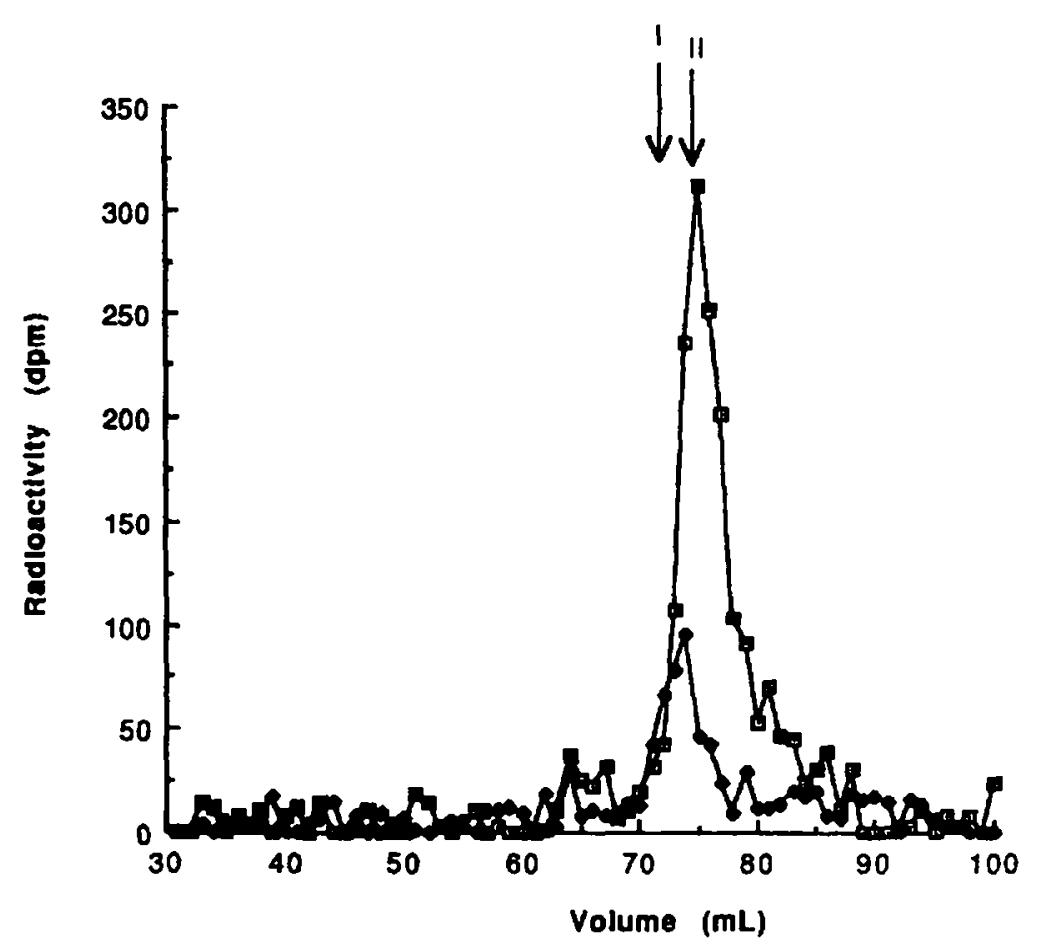

Figure 4. Gel filtration (Bio-Gel P-6) of endo H-treated glycopeptide derived from IVT-Asn (D) or IVT-Gin (*). Glycopeptide substrate for endo $\mathrm{H}$-catalyzed hydrolysis was purified as shown in Figure 3. Arrows I and II indicate the elution volume for the ${ }^{14} \mathrm{C}$-labelled oligosaccharides, $\mathrm{Glc}_{3}\left[{ }^{14} \mathrm{C}\right] \mathrm{Man}_{9}(\mathrm{GlcNAc})_{2}$ and $\left[{ }^{14} \mathrm{C}\right] \mathrm{Man}_{9}(\mathrm{GlcNAc})_{2}$. respectively.

the ${ }^{3} \mathrm{H}$ is in the SDS fraction. Similar competition between the tripeptide substrate and the endogenous P40 proteins is observed with the solubilized OST activity (Table 2, Section A) where the glycoprotein fraction (SDS) is dramatically decreased from ca $55 \%$ in the absence of tripeptide to $\mathrm{ca} 13 \%$ in the presence of tripeptide substrate. As shown in Figure 1, the ${ }^{3} \mathrm{H}$ labelled glycopeptide isolated from the reaction mixture using solubilized OST has very similar chromatographic properties (Bio-Gel P-4) as previously described by us for the glycopeptide derived from the same substrates using microsomal OST. ${ }^{22}$ The data of Section A of Tables 1 and 2 show clearly that the modified proteins are very poor substrates for OST-catalyzed glycosylation. Product analysis using PAGE as described in the Experimental Section showed $<2 \%$ ${ }^{3} \mathrm{H}$ migrating in the gel at the position anticipated for the expected glycoproteins. When the reaction mixtures were analyzed directly by gel filtration chromatography, $<2 \%$ of the ${ }^{3} \mathrm{H}$ from the ${ }^{3} \mathrm{H}$-labelled substrate was observed at the expected elution volume of the presumed glycoprotein product; only $\left[{ }^{3} \mathrm{H}\right]$ LOS was eluted from the column. Most interesting is the apparent inhibition of endogenous protein glycosylation (SDS) by the added modified proteins, i.e. Table 1, Section A, lines $3,4,5$ vs line 1 . These results indicate that the modified proteins are very poor OST substrates but that they may be able to compete with endogenous proteins for the OST enzyme. Additional experiments must be done in order to obtain more extensive data to substantiate further this observation.

To reduce the high background radioactivity observed in the $\mathrm{H}_{2} \mathrm{O}$ fraction in the presence or absence of microsomal OST (P40), the usual extraction procedure 22 was modified slightly in selected experiments. The initial pellet obtained by quenching the reaction with $\mathrm{CHCl}_{3}: \mathrm{MeOH}(2: 1)$, was resuspended in '1103' $\left(\mathrm{CHCl}_{3}: \mathrm{MeOH}: \mathrm{H}_{2} \mathrm{O}, 1: 1: 0.3\right)$ in order to extract the unreacted $\left[{ }^{3} \mathrm{H}\right] \mathrm{LOS}$ more effectively. This was followed by washing of the 1103-insoluble material with $\mathrm{H}_{2} \mathrm{O}(\mathrm{pH} \mathrm{4,} \mathrm{HOAc})$ and dissolving the ${ }^{3} \mathrm{H}$-labelled glycoprotein pellet in SDS. Although the modified procedure was effective in lowering the background radioactivity noted above, in no case did this modified procedure alter the amount of ${ }^{3} \mathrm{H}$-labelled glycoprotein as monitored by gel filtration chromatography or PAGE.

As a result of the experiments using modified proteins described above, we chose to investigate somewhat smaller peptides as potential OST substrates in order to explore the size limitations imposed by the OST active site. Calcitonin has been reported to be an OST substrate ${ }^{28}$ or a non-substrate. ${ }^{14}$ Our results with both the microsomal (Table 1) and solubilized (Table 2) OST activity show clearly that there is no evidence for glycosylation of calcitonin under these conditions. Addition of DTT $(10 \mathrm{mM})$ to the assay in order to reduce the disulfide bridge did not affect the results (Table 1, Section B). However, the next series of potential peptide substrates proved to be much more effective. As shown in Section C of Tables 1 and 2, two 17-amino acid peptides, IVT-Asn and IVT-GIn, derived from the invertase sequence containing two overlapping sequons, ${ }^{29}$ are effective substrates. In comparison with the widely used tripeptide, Bz-Asn-Leu-Thr- $\mathrm{NH}_{2}$, the invertase-derived peptide, IVT-Asn, which retains the unusual overlapping sequons, is only slightly less active 
(Fig. 2). In contrast, the 'mutant' peptide in which Gln replaces the Asn of the first of the overlapping sequons, is markedly less active. Further characterization of the glycopeptide products derived from OST-catalyzed glycosylation of IVT-Asn and IVT-Gln involved gel filtration chromatography of both the $\mathrm{H}_{2} \mathrm{O}$-soluble glycopeptide fraction before (Fig. 3) and after (Fig. 4) endo H-catalyzed hydrolysis of the $1 \rightarrow 4$ intersaccharide bond of the chitobiose moiety in the oligosaccharide portion of the glycopeptide. Both invertase-derived peptides are converted to similar glycopeptide products (Fig. 3) containing the same oligosaccharide structures (Fig. 4). We are currently investigating methods for the rapid determination of the glycosylation site(s) in these and other invertasederived peptides.

The results presented in this paper show clearly that large proteins, even when chemically modified, are not good substrates for OST-catalyzed glycosylation and therefore cannot be converted to homogeneous neoglycoproteins by this method. However, the finding that two peptides derived from invertase are OST substrates provides the foundation for a systematic study of the varied ability to glycosylate apparently competent sequons in invertase and, by extension, other glycoproteins. Although others have carried out limited structure-activity studies on several peptide substrates, ${ }^{14-16}$ the recently developed combinatorial approaches to peptide synthesis and the use of peptide libraries should allow us to carry out efficient and rapid screens of the peptide-binding domains of OST.

\section{Experimental Section}

\section{General}

Previous papers from this laboratory 22,23 contain procedures for the synthesis of peptide substrates, glycopeptide products, assay for microsomal OST activity, chromatographic analyses, and the source of radiolabelled compounds. P40 yeast microsomes and $\left[{ }^{3} \mathrm{H}\right]$ LOS were prepared as described by Clark et al. ${ }^{22}$ Initially, solubilization of microsomal OST activity was carried out using NP-40 according to a slight modification of the procedure of Sharma et al. ${ }^{19}$ This solubilized preparation was used in studies with the tripeptide, Bz-Asn-Leu-Thr- $\mathrm{NH}_{2}$, as substrate. Subsequent experiments using modified proteins and larger peptides as substrates employed solubilized OST from salt-stripped microsomes as described below. All glycopeptide products derived by solubilized OSTcatalyzed glycosylation of Bz-Asn-Leu-Thr- $\mathrm{NH}_{2}$ were isolated as described by Chalifour and Spiro ${ }^{20}$ except that a Dowex cation exchange step was omitted. Calcitonin was purchased from Bachem. Two peptides containing overlapping sequons 4 and 5 from yeast invertase 29 were provided by Dr Frank Maley, New York Department of Health, Albany, NY. The two peptides have the sequence Ala-Phe-Ser-Gly-Ser-MetVal-Val-Asp-Tyr-Asn/Gln-Asn-Thr-Ser-Gly-Phe-Phe and are referred to as IVT-Asn and IVT-Gln depending on the amino acid present at the first putative glycosylation site. IVT-Asn and IVT-Gln were dissolved in DMSO at a concentration of $7.2 \mathrm{mM}$ and the OST. catalyzed reaction was run and the products analyzed as described previously. ${ }^{22}$

\section{Solubilization of OST activity from salt-stripped yeast microsomes}

A suspension of $800 \mu \mathrm{L}$ of yeast microsomal P40 (40$80 \mathrm{mg} / \mathrm{mL})^{22}$ was diluted to $20 \mathrm{~mL}$ with $20 \mathrm{mM}$ Tris-Cl (pH 7.4), $500 \mathrm{mM} \mathrm{NaCl}, 1 \mathrm{mM}$ phenylmethylsulfonyl fluoride (PMSF), and protease inhibitor cocktail (PIC) as described by Kelleher et al. ${ }^{6}$ The suspension was centrifuged at $184,000 \mathrm{gav}$ for $45 \mathrm{~min}$ in a Beckman Ti50 rotor to obtain salt-stripped membranes as the pellet. The pellet was resuspended in $800 \mu \mathrm{L}$ of $50 \mathrm{mM}$ Tris- $\mathrm{Cl}$ (pH 7.4) buffer containing $5 \mathrm{mM} \mathrm{MgCl}, 5 \mathrm{mM}$ $\mathrm{MnCl}_{2}$ buffer. This suspension was stored under $\mathrm{N}_{2}$ at $-80^{\circ} \mathrm{C}$.

Solubilization of the OST activity in the salt-stripped microsomes employed a modification of the method described by Chalifour and Spiro for the solubilization of OST activity from calf thyroids. ${ }^{20} \mathrm{~A}$ stock solution of $1.6 \%$ (w/v) NP-40 was prepared in $50 \mathrm{mM}$ Tris-Cl, pH $7.5,5 \mathrm{mM} \mathrm{MgCl}$, and $5 \mathrm{mM} \mathrm{MnCl}$. To $200 \mu \mathrm{L}$ of saltstripped microsomal suspension was added $200 \mu \mathrm{L}$ of the $1.6 \%$ NP-40 stock solution. The suspension was homogenized in a Dounce homogenizer (5 strokes), and the detergent extract was clarified by centrifugation for $1 \mathrm{~h}$ at $158,000 \mathrm{~g}$ at $4{ }^{\circ} \mathrm{C}$ in a Beckman Ti70.1 rotor. The supernatant was extracted and used immediately in assays .

\section{Preparation of modified proteins}

Sulfitolysis of RNase A. RNase A (bovine pancreas, 10 $\mathrm{mg}$ ) was dissolved in $1.5 \mathrm{~mL}$ of $5 \mathrm{mM} \mathrm{HCl}$, and was diluted with $2.5 \mathrm{~mL}$ of $1 \mathrm{mM} \mathrm{HCl}$. Sulfitolysis was carried out following the procedure of Pechere et al. ${ }^{30}$ To remove the chemical reagents, the mixture was dialyzed against $2 \mathrm{~L}$ of $50 \mathrm{mM}$ Tris-Cl buffer, $\mathrm{pH} 7.5$. The buffer was changed every $4-5 \mathrm{~h}$ in order to increase the efficiency of the dialysis. The concentration of sulfitolyzed RNase A (RA-( $\left.\mathrm{SSO}_{3}^{-}\right)_{8}$ ) in the dialysis bag was checked by UV $\left(\mathrm{E}_{280}{ }^{1 \%}=7.0\right)$. After $30 \mathrm{~h}$ dialysis, the $\mathrm{RA}-\left(\mathrm{SSO}_{3}{ }^{-}\right)_{8}$ solution was concentrated on a Microcon centrifugal filtration unit (Amicon) device (MWCO 10,000) to achieve a concentration of 3-5 $\mathrm{mg} / \mathrm{mL}$ in $50 \mathrm{mM}$ Tris buffer, $\mathrm{pH} 7.5$. The solution was stored at below $0{ }^{\circ} \mathrm{C}$, and was used as the source of RA$\left(\mathrm{SSO}_{3}{ }^{-}\right)_{8}$ in glycosylation assays.

Analysis of the conversion of RNase A to $\mathrm{RA}-\left(\mathrm{SSO}_{3}^{-}\right)_{8}$ was carried out by denaturing (SDS) polyacrylamide gel electrophoresis (PAGE) run at a concentration of 15 \% acrylamide. Glutathione (GSH)-mediated conversion of $\mathrm{RA}-\left(\mathrm{SSO}_{3}{ }^{-}\right)_{8}$ back to RNase $\mathrm{A}$ was carried out by the method of Thannhauser and Scheraga. ${ }^{31}$ All samples for electrophoresis were prepared in the absence of $\beta$ mercaptoethanol. 
Alkylation of $\alpha$-lactalbumin. $\alpha$-Lactalbumin was dialyzed against distilled water overnight to remove salts and stabilizing reagents prior to the carboxymethylation reaction, carried out as described by Brew et al. ${ }^{32}$

Purification of $\mathrm{RA}-\left(\mathrm{SSO}_{3}^{-}\right)_{8}$ and $\mathrm{S}$-carboxymethylated $\alpha$ lactalbumin ( $\left.\mathrm{Lac}-\left(\mathrm{SCH}_{2} \mathrm{CO}_{2}^{-}\right)_{8}\right)$

Sulfitolyzed RNaseA and S-carboxymethylated $\alpha$ lactalbumin were prepared by the procedures described above. At the end of the reaction, the reaction mixture was dialyzed against $\mathrm{H}_{2} \mathrm{O}$ for 3 days and lyophilized.

Lyophilized RA-( $\left.\mathrm{SSO}_{3}{ }^{-}\right)_{8}$ or Lac-( $\left.\mathrm{SCH}_{2} \mathrm{CO}_{2}{ }^{-}\right)_{8}(10 \mathrm{mg})$ was dissolved in $1 \mathrm{~mL}$ of $0.1 \mathrm{M} \mathrm{NaHCO}$. The filtered solution was loaded onto a Sephadex G-75 column (1.5 $\mathrm{cm} \times 60 \mathrm{~cm}$ ) at $4^{\circ} \mathrm{C} .33$ The column was eluted with 0.1 M NaHCO 3 at a flow rate of $15 \mathrm{~mL} / \mathrm{h}$. Fractions of $2 \mathrm{~mL}$ were collected and checked for absorbance at $280 \mathrm{~nm}$. For Lac-( $\left.\mathrm{SCH}_{2} \mathrm{CO}_{2}{ }^{-}\right)_{8}$, the fractions with $\mathrm{UV}$ absorbance were pooled and dialyzed against $\mathrm{H}_{2} \mathrm{O}$ overnight. After lyophilization, the purified material was dissolved in $50 \mathrm{mM}$ Tris- $\mathrm{Cl}, \mathrm{pH} 7.5$ at a concentration of $5 \mathrm{mg} / \mathrm{mL}$. For $\mathrm{RA}-\left(\mathrm{SSO}_{3}{ }^{-}\right)_{8}$, the pooled fractions were loaded onto a Microcon centrifugal unit (Amicon) device (MWCO 10,000) for buffer exchange, accomplished by washing with large quantities of 50 $\mathrm{mM}$ Tris-Cl, pH 7.5 buffer. The final solution of purified $\mathrm{RA}-\left(\mathrm{SSO}_{3}^{-}\right)_{8}$ had a concentration of $\sim 3 \mathrm{mg} / \mathrm{mL}$ in Tris buffer.

\section{Microsomal $P 40$ assay with modified proteins as substrates}

Assay mixture contained 8,000-12,000 dpm of dried $\left[{ }^{3} \mathrm{H}\right]$ LOS, $50 \mathrm{mM}$ Tris-HCl, pH 7.5, $5 \mathrm{mM} \mathrm{MgCl}_{2}, 5$ $\mathrm{mM} \mathrm{MnCl}_{2}, 1 \%(\mathrm{v} / \mathrm{v})$ Triton X-100, $5 \% \mathrm{DMSO}$, and salt-stripped microsomal $\mathrm{P} 40(100-200 \mu \mathrm{g}$ of proteins) in a volume a of $100 \mu \mathrm{L}$. The modified proteins, RA$\left(\mathrm{SSO}_{3}{ }^{-}\right)_{8}$ and $\mathrm{Lac}-\left(\mathrm{SCH}_{2} \mathrm{CO}_{2}^{-}\right)_{8},(200 \mu \mathrm{g})$ were added and the reaction mixture was incubated at ambient temperature for $2 \mathrm{~h}$ with vigorous gyroshaking (250 rpm) and the reaction stopped by the addition of $3 \mathrm{~mL}$ of cold $\mathrm{CHCl}_{3}: \mathrm{MeOH}(2: 1)$. The separation of the reaction products followed procedures described earlier ${ }^{22}$ with the exception that extraction of the glycosylated modified protein was carried out at $\mathrm{pH} 4.0$ in order to improve the solubility of the extracted product.

OST assay with modified proteins as substrates using NP40-solubilized enzyme

A $1.35 \mathrm{mg} / \mathrm{mL}$ phosphatidylcholine (PC) solution was prepared by drying the stock PC ether solution (Sigma, $100 \mathrm{mg} / \mathrm{mI}$ ) in a Speed Vac vacuum centrifuge, then redissolving the residue in a $50 \mathrm{mM}$ Tris $-\mathrm{Cl}, \mathrm{pH} 7.5$ buffer solution containing $5 \mathrm{mM} \mathrm{MgCl}, 5 \mathrm{mM} \mathrm{MnCl}$, and $0.3 \%$ NP40. The OST assay mixture contained $8,000-12,000 \mathrm{dpm}$ of dried $\left[{ }^{3} \mathrm{H}\right] \mathrm{LOS}, 50 \mathrm{mM}$ Tris-HCl, $\mathrm{pH} 7.5,5 \mathrm{mM} \mathrm{MgCl} 2,5 \mathrm{mM} \mathrm{MnCl} 2,0.2 \%(\mathrm{v} / \mathrm{v})$ Triton $\mathrm{X}-100,90 \mu \mathrm{g}$ of phosphatidylcholine, $0.2 \%$ NP40, solubilized OST $(30-50 \mu \mathrm{g})$, and exogenous proteins (50-200 $\mu \mathrm{g}$ ) in a volume of $100 \mu \mathrm{L}$. Isolation of the glycoprotein products was carried out as described in the literature. 20

Analysis of the protein glycosylation assays by polyacrylamide gel electrophoresis (PAGE)

Assays with $10,000 \mathrm{dpm}$ of $\left[{ }^{3} \mathrm{H}\right] \mathrm{LOS}, 200 \mu \mathrm{g}$ of saltstripped $\mathrm{P} 40$ and $100 \mu \mathrm{g}$ of exogenous protein were prepared and incubated as usual. At the end of the incubation, the assay was diluted by $200 \mu \mathrm{L}$ of chilled $50 \mathrm{mM}$ Tris- $\mathrm{Cl}$ buffer, $\mathrm{pH} 7.5$ and centrifuged at 12,000 $g$ for $20 \mathrm{~min}^{25}$ The supernatant was extracted and the pellet was washed again. The combined supernatant (no more than $500 \mu \mathrm{L}$ ) was transferred into the cup of a Microcon centrifugal filtration unit (Amicon), and was concentrated at a centrifugal speed of $12,500 \mathrm{~g}$ for 1.5 to $2 \mathrm{~h}$ at $4^{\circ} \mathrm{C}$. At this time, $20 \mu \mathrm{L}$ of electrophoretic sample buffer (non-reducing) was added into the Microcon cup and vortexed to dissolve any proteins that were absorbed to the membrane. The concentrate, together with the sample buffer was then removed from the Microcon unit and used in electrophoresis.

Denaturing $15 \%$ acrylamide slab gels (1.5 mm thick) were prepared with five large wells so as to accommodate the volume of the samples. After the samples were loaded, the electrophoresis was continued for $\sim 1 \mathrm{~h}$ until the tracing dye had reached the bottom of the gel. The gel was subsequently fixed, stained and destained to remove any radioactivity on the surface of the gel. Before slicing, the gel was soaked in water for 15-30 min to recover the original size. During slicing, the gel was first sliced vertically into different lanes. The lane of interest was then sliced horizontally into 2 $\mathrm{mm}$ slices on a gel cutter. Each slice was next transferred into a $20 \mathrm{~mL}$ glass scintillation vial to which $0.5 \mathrm{~mL}$ of $\mathrm{H}_{2} \mathrm{O}$ and $0.5 \mathrm{~mL}$ of the tissue solubilizer, "Solvable" (NEN), were added. After incubating the slices at $50{ }^{\circ} \mathrm{C}$ for $2-3 \mathrm{~h}, 10 \mathrm{~mL}$ of scintillation cocktail was added into each vial and vortexed vigorously. The vials were set at $\mathrm{nt}$ overnight before being counted.

\section{Glycosylation of calcitonin and analysis of the reaction products}

The standard assay for peptide substrates 22 was employed using 50-100 $\mathrm{gg}$ of calcitonin (salmon I), and salt-stripped microsomal P40 (100-200 $\mu \mathrm{g}$ of proteins). When indicated, $10 \mathrm{mM}$ DTT was also included in the assay. The incubation was continued at $\mathrm{rt}$ for the times indicated in Tables 1 and 2. The standard fractionation method was used to isolate the glycopeptide product. ${ }^{22}$

To analyze the glycosylation products, the reaction was quenched with $100 \mu \mathrm{L}$ of cold $50 \mathrm{mM}$ Tris- $\mathrm{Cl}, \mathrm{pH} 7.5$. The mixture was centrifuged at $10,000 \mathrm{~g}$ for $15 \mathrm{~min}$. The pellet was washed again, and the combined supernatant was loaded onto a Bio-Gel P-6 column $(1.5 \mathrm{~cm} \times 70$ $\mathrm{cm})$. The column was eluted with $0.1 \mathrm{M} \mathrm{NH}_{4} \mathrm{HCO}_{3}, \mathrm{pH}$ 7.5 at a flow rate of $8 \mathrm{~mL} / \mathrm{h} .^{28}$ Fractions of $1 \mathrm{~mL}$ were collected and aliquots were counted for radioactivity. 


\section{Bio-Gel P-6 analysis of glycosylated invertase peptides}

$\mathrm{H}_{2} \mathrm{O}$ fractions from the glycosylation assays of the invertase peptides were dried in a Speed Vac vacuum centrifuge and redissolved in $500 \mu \mathrm{L}$ of $0.1 \mathrm{M}$ $\mathrm{NH}_{4} \mathrm{HCO}_{3}, \mathrm{pH} 7.5$. After centrifugation, the solution was loaded onto a Bio-Gel P-6 column $(1.5 \mathrm{~cm} \times 70 \mathrm{~cm})$. The column was eluted with $0.1 \mathrm{M} \mathrm{NH}_{4} \mathrm{HCO}_{3}, \mathrm{pH} 7.5$ at a flow rate of $8 \mathrm{~mL} / \mathrm{h}$. Fractions of $1 \mathrm{~mL}$ were collected, and aliquots were counted for radioactivity. Fractions containing the putative glycosylated invertase peptides were pooled and lyophilized.

The lyophilized glycosylated invertase peptide $(1,000$ $5,000 \mathrm{dpm}$ ) from the previous Bio-Gel P-6 column purification was incubated with $50 \mathrm{mIU}$ endo $\mathrm{H}$ in 500 $\mu \mathrm{L}$ of $250 \mathrm{mM} \mathrm{Na}$ Citrate, $\mathrm{pH} 5.5$ at $37^{\circ} \mathrm{C}$ for $20 \mathrm{~h}$ as previously described ${ }^{22}$ and the products analyzed by Bio-Gel P-6 chromatography as described above. The column was first calibrated with a sample of $\mathrm{Glc}_{3}\left[{ }^{14} \mathrm{C}\right]$ Mang $_{9}(\mathrm{GlcNAc})_{2}$ and $\left[{ }^{14} \mathrm{C}\right] \mathrm{Man}_{9}(\mathrm{GlcNAc})_{2}$.

\section{Acknowledgments}

This research has been supported by funds provided by the College of Pharmacy, University of Michigan, in the form of a Vahlteich Fellowship to Y.-L. L. and also by a fellowship to Y.-L. L. from the Program in Protein Structure and Design, University of Michigan. We gratefully acknowledge the gift from Dr Frank Maley of two invertase-derived peptides used in this research. Initial studies on the solubilization of OST activity were carried out by Dr Richard Clark. We thank Mrs Jane MacDonald for careful preparation of this manuscript.

\section{References and Notes}

1. Hubbard, S. C.: Ivatt, R. J. Ann. Rev. Biochem. 1981, 50,555.

2. Hirschberg, C. B.; Snider, M. D. Ann. Rev. Biochem. 1987 , $56,63$.

3. Elbein, A. D. Ann. Rev. Biochem 1987, 56, 497.

4. Rademacher, T. W.; Parekh, R. B.; Dwek, R. A. Ann. Rev. Biochem. 1988, 57,785 .

5. Kaplan, H. A.; Welply, J. K.; Lennarz, W. J. Biochim. Biophys. Acta 1987, 906, 161.

6. Kelleher, D. J.; Kreibich, G.; Gilmore, R. Cell 1992, $99,55$.

7. Silberstein, S.; Kelleher, D. J.; Gilmore, R. J. Biol. Chem. $1992,267,23658$.
8. te Heesen, S.; Janetzky, B.; Lehle, L.; Aebi, M. EMBO J. $1992,11.2071$.

9. te Heesen, S.; Knauer, R.; Lehle, L.; Aebi, M. EMBO J. $1993,12,279$.

10. Paulsen, J. C. TIBS 1989, 14, 272.

11. Elbein, A. D. T7BTECH 1991, 9, 346.

12. Lodish, H. F. TIBS 1991, 16, 374.

13. Varki, A. Glycobiology 1993, 3,97.

14. Ronin. C.: Granier, C.; Caseti, C.: Bouchilloux, S.; Van Rietschoten, J. Eur. J. Biochem. 1981 , 118, 159.

15. Welply, J. K.; Shenbagamurthi, P.; Lennarz, W. J.; Naider, F. J. Biol Chem 1983, 258, 11856.

16. Lehle, L.; Bause, E. Biochim. Biophys. Acta 1984, 799, 246.

17. Lehle, L.; Tanner, W. Eur. J. Biochem 1978, 83, 563.

18. Jackson, B. J.; Warren, C. D.; Bugge, B.; Robbins, P. W Arch. Biochem. Biophys. 1989, 272, 203.

19. Sharma, C. B.; Lehle. L.; Tanner, W. Eur. J. Biochem. $1981,116,101$.

20. Chalifour, R. J.; Spiro, R. G. J. Biol. Chem. 1988, 263. 15673.

21. Franc, J.-L.; Bouchilloux, S. Biochim. Biophys. Acta 1984, $800,166$.

22. Clark, R. S.; Banerjec, S.; Coward, J. K. J. Org. Chem. $1990,55,6275$

23. Lee, J.; Coward, J. K. J. Org. Chem. 1992, 57, 4126.

24. Lee, J.; Coward, J. K. Biochemistry 1993, 32, 6794.

25. Pless, D. D.; Lennarz, W. J. Proc. Natl Acad. Sci. U.S.A. $1977,74,134$.

26. Kronquist, K. E.; Lennarz, W. J. J. Supramol. Struct. 1978 , $8,51$.

27. Joao, H. C.; Scragg, I. G.; Dewk, R. A. FEBS Lett. 1992 , 307, 343.

28. Jacobs, J. W.; Simpson, E.; Lennarz, W. J.; Welply, J. K. Biochem. Biophys. Res. Commun. 1985, 130, 343.

29. Reddy, V. A.; Johnson, R. S.; Biemann, K.; Williams, R. S.; Ziegler, F. D.; Trimble, R. B.; Maley, F. J. Biol. Chem. $1988,263,6978$

30. Pechere, J. F.; Dixon, G. H.; Maybury, R. H.; Neurath, H. $l$ Biol. Chem. 1958, 233, 1364.

31. Thannhauser, T. W.; Scheraga, H. A. Biochemistry 1985 , 24,7681 .

32. Brew, K.; Castellino, F. J.; Vanaman, T. C.; Hill, R. L. J. Biol. Chem. 1970, 245, 4570.

33. Elting, J. J.; Lennarz, W. J. Methods Enzymol. 1982, 83, 408. 